Prof. dr. sc. Nenad Đurđević, redovni profesor

Pravnog fakulteta u Kragujevcu

\title{
SLUČAJ PECHSTEIN - PUNOVAŽNOST ODLUKA ARBITRAŽNOG SUDA ZA SPORT U LOZANI (CAS) I NJIHOVO PRIZNAVANJE PRED NACIONALNIM SUDOVIMA
}

\author{
UDK: 341.6 796/799: \\ Primljeno 1.10.2016. \\ Izvorni znanstveni rad
}

\begin{abstract}
Uporedno-pravna rešenja podstiču arbitražno rešavanje sporova u oblasti sporta, a pravila mnogih međunarodnih sportskih saveza zabranjuju članicama da vode sudske sporove pod pretnjom zabrane nastupa na međunarodnim takmičenjima. Najznačajniji i najpopularniji arbitražni sud za razrešavanje međunarodnih sporova u domenu sporta jeste Arbitražni sud za sport Lozani (The Court of Arbitration for Sport - CAS) sa sedištem u Lozani (Švajcarska). Da bi CAS bio nadležan za rešavanje određenog spora, on mora biti podoban za arbitražu i mora postojati punovažan arbitražni sporazum. Osim toga, za punovažnost odluka CAS-a važe isti procesni zahtevi kao i za odluke državnih sudova: nezavisnost suda, pravo stranke da bude saslušana, pravo na pošteno suđenje, zabrana retroaktivnih pravila i kazni, načelo ne bis in idem, načelo proporcionalnosti u odmeravanju kazne, načelo nezavisnosti sudije, načelo pisanog obrazloženja odluke. Autor u radu razmatra pitanje punovažnosti i obaveznosti odluka koje donosi CAS i mogućnosti njihovog osporavanja pred nacionalnim sudovima, kako nacionalnim sudovima prema sedištu CAS-a tako i nacionalnim sudovima strana u sportu (u postupku izvršenja odluka CAS-a ili nezavisno od toga). Ovo pitanje je posebno razmotreno u svetlu tzv. slučaja Pechstein (tužba Claudie Pechstein protiv International Skating Union za naknadu štete zbog dvogodišnje zabrane takmičenja usled dopinga) koji je svoj epilog dobio presudom nemačkog Vrhovnog saveznog suda (Bundesgerichtshof) od 7. juna 2016. godine, a ticao se upravo punovažnosti arbitražnog sporazuma o nadležnosti CAS-a i priznavanja odluke CAS-a, kao strane arbitražne odluke, od nemačkih sudova.
\end{abstract}

Ključne reči: sport, arbitraža, Pechstein, doping, arbitražna odluka, CAS, arbitražni sporazum, nezavisnost arbitara

Najznačajniji i najpopularniji arbitražni sud za razrešavanje međunarodnih sporova u domenu sporta jeste Arbitražni sud za sport (CAS) sa sedištem u Lozani, Švajcarska. U proseku, oko 300 slučajeva iz sveta sporta se godišnje odlučuje pred ovim arbitražnim sudom. Odluke CAS-a nisu neposredni izvor međunarodnog sportskog prava. Međutim, u pravnoj literaturi se s pravom ističe da odluke CAS-a predstavljaju vodilju za buduće predmete pred CAS-om i postupno stvaraju lex 
sportiva. ${ }^{l}$ CAS je jako popularan u razrešavanju međunarodnih sporova u domenu sporta zato što eliminiše dosta problema koji se u ovakvim slučajevima javljaju, primenjujući brze i fleksibilne procedure. Ovakvi kvaliteti dozvoljavaju da se arbitraža prilagodi potrebama i željama strana koje su u spor uključene. ${ }^{2}$

\section{NADLEŽNOST CAS-A I ARBITRAŽNI SPORAZUM}

Arbitražni sud za sport je nadležan za "sportske sporove". Samo su ti sporovi arbitrabilni. O kojim je to sporovima reč, određuje čl. čl. R27 (2) „International Code of Sports Related Arbitration“ - CAS Code. Pod sportskim sporom se smatra svaki spor koji je na direktan ili indirektan način povezan za sportom, odnosno koji uključuje neku aktivnost koja se odnosi ili je vezana za sport i koji uključuje novčane ili druge interese koji su povezani sa praksom i razvojem sporta. Međutim, nije svaki spor u vezi sporta i podoban za arbitražu. CAS, načelno, nije nadležan da preispituje odluke koje su donele sudije, delegati i drugi sportski zvaničnici odgovorni za primenu pravila igre na sportskom terenu. Samo izuzetno je moguće i ovakve odluke preispitivati u postupku pred CAS-om, u slučaju kada žalilac može pružiti neposredne dokaze zle namere donosioca odluke. ${ }^{3}$

Kao i svaka druga međunarodna arbitraža, CAS može odlučivati o predmetu spora samo ukoliko postoji punovažan arbitražni sporazum. Samo na osnovu punovažnog arbitražnog sporazuma može se utemeljiti nadležnost arbitraže i doneti odluka koja se može izvršiti, posebno jer je opštepoznato da je svaka arbitraža onoliko dobra koliko je dobar arbitražni sporazum. ${ }^{4}$ Da bi arbitražni sporazum bio punovažan, on mora biti rezultat saglasnosti volja strana u sporu i mora ispunjavati određene uslove koji se tiču forme, sadržine i sposobnosti stranaka da ga zaključe.

Odredbe relevantne za arbitražni sporazum su sadržane u čl. S1 i čl. R27 CAS Code. Arbitražni sporazum može biti u vidu arbitražne klauzule, bilo kao deo, odnosno klauzula ugovora o osnovnom poslu, bilo kao odredba u statutu ili drugom opštem aktu nadležnog sportskog saveza, pristupnici za prijem u članstvo sportskog saveza, prijavi za određeno sportsko takmičenje, zahtevu za registraciju, zahtevu za licenciranje i sl., a može i biti u formi arbitražnog sporazuma, odnosno u vidu posebnog arbitražnog ugovora zaključenog nakon nastanka spora.

1 James A. R. Nafziger, "The Principle of Fairness in the Lex Sportiva of CAS Awards and Beyond", The International Sports Law Journal, br. 3-4\&2010, str. 3, www.asser.nl/upload/ documents/20131023T040218-ISLJ_2010-3-4.pdf.

2 Videti, Walter Gerhard: Die Entscheidungen der „,Disziplinkammer fuer Doping faelle von Swiß Olympic-erste Erfahrungen“", Sport und Recht, Heft 2/2004, str. 88.

3 Više videti: Ian Blackshaw, "ADR and Sport: Settling Disputes Through the Court of Arbitration for Sport, the FIFA Dispute Resolution Chamber, and the WIPO Arbitration \& Mediation Centar", Marquette Sports Law Review, Vol. 24, Iss.1, 2013., str. 17-18.

4 Milena Petrović, "Punovažnost arbitražnog sporazuma”, Zbornik radova „Harmonizacija građanskog prava u regionu “, Istočno Sarajevo, 2013., str. 479-497. 
Arbitražni sporazum ima ograničeno dejstvo kada je sadržan u prijavi za određeno takmičenje. Prema stanovištu Vrhovnog federalnog suda Švajcarske, iznetom u slučaju WADA v.F.\& IIHF, ovaj arbitražni sporazum ima ograničeno dejstvo, odnosno važi samo za ono takmičenje za koje su mesto i vreme održavanja izričito navedeni u prijavi. ${ }^{5}$

Arbitražni sporazum je u praksi najčešće sadržan u odredbama statuta i opštih akata nadležnih međunarodnih i nacionalnih sportskih saveza, u skladu sa članom R47 CAS Code. Iako je kod ovakvog "nametanja" arbitražnog sporazuma načelno sporna stvarna saglasnost volja stranaka da odustanu od sudske zaštite, u literaturi i praksi se valjanost takvog arbitražnog sporazuma opravdava, s jedne strane, koristima koje imaju svi učesnici u sistemu sporta od brzog rešavanja sportskih sporova, a, s druge strane, autonomijom sporta i činjenicom da sva lica kada postaju članovi određene sportske organizacije ili saveza daju izjavu o prihvatanju pravila tih organizacija, što podrazumeva i da su upoznati sa njihovom sadržinom. Vrhovni federalni sud Švajcarske je u svojoj presudi od 18. aprila 2011. (4A_640/2011) potvrdio da je arbitražna klauzula važeća i kada je u formi opšteg (globalnog) upućivanja na statut nadležnog međunarodnog sportskog saveza (u konkretnom slučaju statut FIFE). Prema stanovištu suda, kada se u sportskim pitanjima razmatra da li su stranke postigle arbitražni sporazum tome treba prići sa izvesnom "dobronamernošću", sve sa ciljem da se sporovi brzo reše pred specijalizovanim sudom koji, poput CAS-a, jemče dovoljnu nezavisnost i nepristrasnost. ${ }^{6}$

U svakom slučaju, postojanje nadležnosti CAS-a za rešavanje konkretnog spornog pitanje ne može se olako pretpostavljati. Postojanje zajedničke namere stranaka da spor povere CAS-u može se prihvatiti samo ako nema sumnje da su stranke želele da isključe nadležnost državnih sudova. ${ }^{7}$

\section{PUNOVAŽNOST I IZVRŠNOST ODLUKA CAS-A}

Arbitražna odluka CAS-a je po svojoj prirodi konačna, izvršna i pravno obavezujuća. Nezavisnost Sportskog arbitražnog suda od MOK-a potvrđena je 2003. godine odlukom švajcarskog Vrhovnog federalnog (saveznog) suda, u sporu ruskih skijaša sa Međunarodnim olimpijskim komitetom i Međunarodnom skijaškom federacijom. ${ }^{8}$ Tada je Vrhovni federalni sud Švajcarske potvrdio nezavisnost

5 Videti presudu 4A 358/2009 od 6. novembra 2009., A. v. WADA (poništena odluka CAS 2008/A/1564, WADA v.F.\& IIHF, od 23. juna 2009.), www.swissarbitrationdecisions.com/sites/default/ files $/ 6 \% 20$ novembre $\% 202009 \% 204 \mathrm{~A} \% 20358 \% 202009$.pdf.

6 Odluka je doneta na osnovu člana 178. PILA, http://relevancy.bger.ch/php/aza/http/index. php?lang=de\&zoom $=\&$ type $=$ show_document\&highlight_docid=aza $\% 3$ A $\% 2$ F\%2F18-04-20114A_640-2010.

Videti presudu Vrhovnog federalnog suda Švajcarske, 4A_244/2012 od 17. I. 2013. godine, http:// www.swissarbitrationdecisions.com/sites/default/files/17\%20janvier\%202013\%204A\%20244\%202012. pdf.

8 Videti: [Swiss Federal Tribunal] May. 27, 2003, III Arêtes du Tribunal Federal Suisse [ATF]129 445 (Switz.), translated into English in Matthieu Reeb, Digest of CAS Awards Ill, 2001-2003, 688545 (2004.). 
CAS-a, naglašavajući činjenicu da je CAS "istinski vrhovni sud svetskog sporta”, i da su pruženi svi dokazi i garancije njegove nezavisnosti i nepristrasnosti kao osnovnih odlika jedne arbitražne institucije, čija su rešenja uporediva i jednaka sa odlukama državnog suda.

Prethodno rečeno ne znači da arbitražne odluke CAS-a nije moguće pravno osporiti. To je moguće putem: 1) tužbe za poništaj arbitražne odluke; 2) kontrole arbitražne odluke u postupku njenog priznanja i izvršenja.

Za svaku arbitražu, pa time i CAS-a, sedište arbitraže ima posebno i veliko značenje, budući da je pravo zemlje u kojoj je sedište arbitraže (lex loci arbitri) istovremeno i pravo koje upravlja arbitražom (lex arbitri). ${ }^{9}$ Lex arbitri određuje i poreklo arbitražne odluke, koje je odlučujuće za njen poništaj ili priznanje i izvršenje. Kako je sedište CAS-a u Lozani, Švajcarska, to je švajcarsko pravo i švajcarski Zakon o međunarodnom privatnom pravu (PILA) lex arbitri za pitanje poništaja arbitražne odluke CAS-a.

Odluke CAS-a podležu kontroli Vrhovnog federalnog suda Švajcarske. Prema čl. 190(2) PILA, postupak za poništaj, koji se pokreće tužbom za poništaj koja se mora podneti u roku od 30 dana od dana prijema odluke, može se inicirati samo u sledećim slučajevima: a) ako solo arbitar nije valjano imenovan ili ako arbitražno veće nije valjano konstituisano; b) ako je arbitražno veće pogrešno odlučilo da jeste ili nije nadležno za rešavanje spora; c) ako je u odluci odlučeno o zahtevima koji nisu podneti (ultra petita) ili ako o nekom zahtevu nije uopšte odlučeno; d) ako nije poštovana jednakost stranaka ili njihovo pravo da se izjasne u kontradiktornom postupku; e) ako je odluka nespojiva sa javnim poretkom. Međutim, švajcarsko pravo dopušta strankama, kada ni jedna od njih nema prebivalište, uobičajeno boravište, niti pak mesto poslovanja u Švajcarskoj, pravo da sporazumom o arbitraži ili nekim drugim kasnijim pismenim sporazumom, isključe svaki pravni lek protiv odluke arbitražnog suda, ili da limitiraju osnove pobijanja samo na jedan ili više razloga navedenih u čl. 190(2) PILA. ${ }^{10}$ U slučaju kada su stranke isključile mogućnost poništaja arbitražne odluke, a njeno izvršenje treba da se sprovede u Švajcarskoj, analogno se primenjuju odredbe Njujorške konvencije o priznanju i izvršenju stranih arbitražnih odluka. Sam, pak, postupak po tužbi za poništaj se sprovodi u skladu sa čl. 77. Zakona o Vrhovnom federalnom sudu iz 2005. godine. ${ }^{11}$ Tužilac u postupku za poništaj mora biti: a) stranka u arbitražnom postupku, b) lice na koje se odluka po žalbi direktno odnosi ili c) lice čiji je lični, stvarni ili pravno zaštićen interes doveden u pitanje. ${ }^{12}$

U dosadašnjoj praksi, Vrhovni federalni sud Švajcarske je samo u zanemarljivo malom broju slučajeva u odnosu na njihov broj osporio dejstvo odluke CAS-a. Ukoliko je arbitražna odluka CAS-a poništena od strane Vrhovnog federalnog suda

9 Gašo Knežević - Vladimir Pavić, Arbitraža i ADR, Beograd, 2010., str. 106.

10 Čl. 192. PILA.

11 Čl. 191. PILA.

12 Više videti, A. Rigozzi, "Challenging Awards of the Court of Arbitration for Sport”, Journal of International Dispute Settlement, Vol.1, No.1. 2010., str. 224. 
Švajcarske, ona ne proizvodi pravno dejstvo ne samo u zemlji u kojoj je sproveden postupak njenog poništenja nego i u većini zemalja potpisnica Njujorške konvencije o priznanju i izvršenju inostranih arbitražnih odluka iz 1958. godine (Njujorška konvencija). ${ }^{13}$ Članom V stav 1. Njujorške konvencije je predviđeno: „Priznanje i izvršenje odluka biće odbijeni, na zahtev stranke protiv koje se odluka ističe, jedino ako ta stranka podnese dokaz nadležnoj vlasti zemlje u kojoj su traženi priznanje i izvršenje: ... (e) da odluka još nije postala obavezna za stranke ili da ju je poništila ili obustavila nadležna vlast u zemlji u kojoj, ili na osnovu čijeg je zakona doneta odluka". ${ }^{14}$

Odluke CAS-a su izvršne, u skladu sa Njujorškom konvencijom o priznanju i izvršenju inostranih arbitražnih odluka. ${ }^{15}$ Njihovo izvršenje može se sprovesti od strane Vrhovnog federalnog suda Švajcarske ili preko nacionalnih sudova zemalja potpisnica Njujorške konvencije. U praksi se, međutim, retko kada koristi ovaj mehanizam, jer su mnogo efikasnije interne procedure nadležnih međunarodnih i nacionalnih sportskih saveza za izvršenje odluke CAS-a. Uslovi pod kojim priznanje i izvršenje strane arbitražne odluke može da bude odbijeno, regulisani su članom V Njujorške konvencije.

\section{SLUČAJ PECHSTEIN}

Jedan od najvećih izazova za budućnost CAS-a i njegov rad, a može se slobodno reći i značaj i prirodu arbitražnog rešavanja sporova u sportu na međunarodnom nivou, predstavljao je tzv. slučaj Pechstein, tačnije tužba koju je pred nemačkim sudovima podnela Claudia Pechstein protiv Međunarodne klizačke unije (International Skating Union - ISU) i Nemačkog klizačkog saveza za naknadu štete zbog odluke o dvogodišnjoj zabrani učešća na takmičenjima usled dopinga, a koju odluku je potvrdio CAS u arbitražnom postupku. Mi ćemo zbog obima ovog rada ukazati samo na neke osnovne karakteristike ovog slučaja i zauzetih pravnih stanovišta.

Claudia Pechstein je vrhunski sportista međunarodnog ranga u brzom klizanju, koji je od bavljenja sportom ostvarivala i značajne prihode. Tužba koju je Pechstein

13 O tužbi za poništenje presude arbitražnog suda u hrvatskom pravu videti: Jozo Čizmić - Hrvoje Momčinović, "Športsko arbitražno sudište HOO - organizacijske i postupovne odredbe", Zbornik radova Pravnog fakulteta u Splitu, br. 4/2011, str. 759-773; Siniša Triva - Alan Uzelac, Hrvatsko arbitražno pravo - Komentar zakona o arbitraži i drugi izvori hrvatskog arbitražnog prava, Zagreb, 2007.

14 U velikoj većini zemalja potpisnica Njujorške konvencije je prihvaćena tzv. teoritorijalna koncepcija međunarodne trgovinske arbitraže, po kojoj pravni sistem države sedišta arbitraže daje pravnu snagu arbitražnoj odluci, pa izvršenje arbitražne odluke koju je poništio nadležni sud te države ne bi bilo koguće nigde u svetu. Postoje, međutim, i zemlje, poput Francuske i SAD, u kojima je dopušteno i priznanje i izvršenje stranih arbitražnih odluka koje su poništene u zemlji sedišta arbitraže (zemlja porekla), primenom principa ,najpovoljnijeg prava“. U tim zemljama se smatra da član VII Njujorške konvencije ima primat u odnosu na član 5. ove Konvencije. Takvo stanovište se temelji na prihvatanju teorije o internacionalnističkoj koncepciji međunarodne arbitraže. Videti Katarina Jovičić, Preispitivanje odluka međunarodnih trgovinskih arbitraža u postupku poništenja, Beograd, 2009., str. 60-67.

15 http://www.tas-cas.org/en/arbitrage.asp/4-3-293-1023-4-1-1/5-0-1023-3-0-0/ 
podnela Zemaljskom sudu u Minhenu sastojala se u zahtevu za utvrđivanje protivpravnosti odluke o zabrani nastupa na takmičenjima koja je izrečena protiv tužilje 2009. godine zbog dopinga, plaćanje naknade štete u visini od 3.584.126,09 eura, kao i plaćanje primerene naknade neimovinske štete (bolnine) kao utvrđivanje obaveze za nadoknadom šteta koje nastanu u budućnosti (ukupno 4,4 miliona eura).

Tužba je podneta protiv Nemačkog klizačkog saveza (prvo tuženi), sa sedištem u Minhenu, i ISU (drugo tuženi), sa sedištem u Švajcarskoj. Oba saveza imaju monopolski položaj u grani sporta za koju su osnivani, po tzv. „Ein-Platz-Princip“, što podrazumeva da postoji samo jedan međunarodni i samo jedan nemački savez za brzo klizanje koji na međunarodnom, odnosno nacionalnom nivou organizuje i nudi takmičenja u grani sporta „brzo klizanje“. Tužilja je član kluba E., koji je član Nemačkog klizačkog saveza, a koji je opet član ISU-a.

Pechstein i Nemački klizački savez su 31. X. 2008. godine zaključili međusobni ugovor (Athletenvereinbarung) kao i arbitražni ugovor, koji su isključivali redovni sudski postupak u slučaju sporova iz zaključenog ugovora, s izuzetkom sporova koji su u nadležnosti disciplinske komisije saveza i sporova u vezi povrede antidoping pravila, i upućivali na rešavanje spora pred Deutschen Instituts für Schiedsgerichtsbarkeit e. V. - DIS. Iste stranke su 15. XI./12. XII. 2011. godine ponovo zaključile međusobni ugovor, koji je u tački 10. predvideo isključenje redovnog sudskog postupka i u disciplinskim pitanjima i pitanjima povrede antidoping pravila, uz nadležnost Nemačkog sportskog (arbitažnog) suda za konačno arbitražno rešavanje sporova. Potvrđena je, takođe, važnost svih ranijih arbitražnih sporazuma kao i važnost par. 13. i 14. Statuta Nemačkog klizačkog saveza, koji isključuju sudsko rešavane sporove i upućuju u pitanjima dopinga na arbitražno rešavanje sporova pred Nemačkim sportskim sudom. Nemački klizački savez je saopštio tužilji da je zaključenje arbitražnog sporazuma uslov za finansijsku podršku saveza i za nominovanje za učešće na međunarodnim takmičenjima.

Kada je u pitanju odnos Pechstein prema ISU-u, tužilja je 2. januara 2009. godine potpisala tipsku, unapred pripremljenu prijavu za nastup na Svetskom prvenstvu u brzom klizanju koje se održavalo 7/8. II. 2009. godine u Hamaru, što je bilo uslov za nastup na takmičenju. Potpisivanjem prijave tužilja je izričito prihvatila statut ISU-a, nadležnost Disciplinske komisije ISU-a i Arbitražnog suda za sport u Lozani za konačno i obavezujuće rešavanje svih sporova, uz isključenje redovnog sudskog postupka. U samom, pak, statutu ISU-a pravi se razlika da li CAS postupa kao prvostepena instanca ili kao žalbena instanca. Prema čl. 25. st. 6. Statuta iz 2012. (istovetan tekst je bio i u čl. 24. ranijeg statuta iz 2006.), CAS je nadležan kao žalbena instanca, za konačno odlučivanje, za sve odluke disciplinske komisije Unije. U tački VI prijave za nastup na Svetskom prvenstvu nalazilo se upućivanje na Antidoping pravila ISU-a, uz izjavu sportiste da prihvata ta pravila. Ova pravila se suštinski podudaraju sa Antidoping pravilima Svetske antidoping agencije, odnosno Svetskim antidoping kodeksom. U čl. 2.2. tih pravila se nalazi i odredba prema kojoj je dopušteno indirektno dokazivanje povrede antidoping pravila putem indicija koje 
ukazuju na korišćenje nedopuštenih metoda (npr. poput manipulacije krvlju) za povećanje sportskog učinka.

Prilikom uzimanja uzorka krvi od tužilje 6. II. 2009. pred početak Svetskog prvenstva, koju je sprovela ISU, izmerena je vrednost Retikulozytena od 3,49 \%. Tokom 7. II. 2009. godine uzeta su još dva uzorka krvi u kojima je utvrđena vrednost Retikulozytena od 3,54 \% i 3,38 \%. U uzetim uzorcima nisu pronađene nikakve antidoping pravilima nedozvoljene supstance. ISU je naknadno uzela još jedan uzorak krvi 18. II. 2009. godine u kome je izmerena vrednost (aparatom marke Avdia) Retikulozytena od 1,37\%. Pechstein nije zbog ovih dešavanja učestvovala na Svetskom prvenstvu.

Međunarodna klizačka unija je 5. III. 2009. godine pokrenula protiv tužilje disciplinski postupak na osnovu povećane vrednosti Retikulozytena zbog povrede Antidoping pravila, smatrajući da te vrednosti predstavljaju indirektan dokaz za doping. Unija je u postupku posebno istekla da prema njenom Programu za testiranje putem uzorka krvi procentualna verovatnoća da se kod pojedinca pojavi vrednost Retikulozytena preko $2,4 \%$ leži ispod $1 \%$. Nemački klizački savez se priključio disciplinskom postupku. Angažovani veštak nije u postupku mogao da se izjasni o tome da li je povećana vrednost možda posledica neke retke bolesti tužilje, ističući da bi za to bilo potrebno dugotrajno ispitivanje. Disciplinska komisija je 1. VII. 2009. godine na osnovu čl. 2.2. Antidoping pravila ISU-a donela odluku o zabrani takmičenja tužilje na dve godine, počev od 9. februara 2009. godine. Disciplinska komisija je u svojoj odluci istakla da ne može da isključi mogućnost da su vrednosti u krvi tužilje posledica neke znatne bolesti krvi, ali pošto je takva mogućnost veoma neverovatna (minimalno moguća), kao i da se tužilja nije podvrgla detaljnim istraživanja njenog zdravlja čime je onemogućila Komisiju da utvrdi bolest kao alternativni uzrok za vrednosti u krvi. Dopisom od 19. VII. 2009. godine, Nemački klizački savez je obavestio tužilju da je na osnovu čl. 10.10.1 Antidoping pravila ISU-a isključena nakon odluke Disciplinske komisije ISU-a i SAC-a i iz sportskog udruženja čiji je član kao i da nema mogućnosti da učestvuje na treninzima i takmičenjima koji se organizuju u ingerenciji saveza.

Pechstein je 21. VII. 2009. godine podnela žalbu CAS-u na odluku Disciplinske komisije ISU-a. Žalbu je takođe podneo i Nemački klizački savez. Usmeni pretres pred CAS-om održan je 22/23. X. 2009. godine. Stranke u postupku nisu imale primedbe na sastav arbitražnog veća, a potpisale su i pravila za sprovođenje arbitraže. Arbitražno veće nije prihvatilo predloge Pechstein za dodatnim veštačenjem kao i predlog da suđenje bude javno. Arbitražno veće CAS-a je donelo arbitražnu odluku 23. XI. 2009. godine, kojom je potvrdilo odluku Disciplinske komisije ISU-a. Arbitražno veće je posebno istaklo da krivica tužilje nije uslov za njenu odgovornost, a da na osnovu veštačenja specijaliste za hematologiju, koga je izabrala sama tužilja, nije bilo moguće da se utvrdi postojanje nekog bolesnog stanja koje bi opravdalo sporne povećane vrednosti u krvi tužilje.

Pechstein je protiv arbitražne odluke CAS-a podnela tužbu za poništenje Vrhovnom federalnom sudu Švajcarske, na osnovu čl. 190. st. 2. PILA. Vrhovni 
federalni sud je svojom presudom od 10. II. 2010. godine (4A_612/2009) odbio tužbu, pošto nije našao ni jedan od razloga iz čl. 190. st. 2. PILA za poništenje arbitražne odluke. Na osnovu jednog medicinskog stručnog mišljenja koje je izneto prvi put na jednom Kongresu u maju 2009. godine, a ticalo se algoritama za procenu vrednosti u krvi, Pechstein je podnela reviziju Vrhovnom federalnom sudu Svajcarske. Ovaj sud je, međutim, tu reviziju odbacio 28. IX. 2010. (4A_144/2010), ističući da tužilja nije pružila dovoljne dokaze zašto nije bilo moguće da se tokom arbitražnog postupka pozove na otkrivene mogućnosti dijagnostikovanja, kao i da novi dokaz ne pobija osnovnu tezu iz arbitražne odluke da bolesti tužilje nisu mogle da objasne konkretna odstupanja u krvnim vrednostima (parametrima). ${ }^{16}$

Tokom 2012. godine Pechstein je podnela tužbu Zemaljskom sudu u Minhenu sa zahtevom da se utvrdi nepunovažnost odluka o zabrani nastupa na takmičenjima zbog dopinga i da joj se dosudi naknada imovinske i neimovinske štete koju je pretrpela. U postupku pred Zemaljskim sudom u Minhenu, tužilja je tvrdila da vrednosti koje su izmerene u njenoj krvi nisu posledica nikakvog dopinga već vrlo retke urođene krvne anomalije koju je nasledila od oca, a koja je definitivno utvrđena stručnim mišljenjem od 6. II. 2011. nakon brojnih istraživanja uzoraka njene krvi. Bolest se pojačavala sa rastom ekstremnih telesnih opterećenja tužilje na treninzima i takmičenjima. Osim toga, prema navodima Pechstein, do tada nisu postojale poznate metode dopinga koje bi mogle da objasne njenu ukupnu krvnu sliku. Tužilja je posebno istakla da je rok koji je Disciplinska komisija ISU-a odredila za njeno ispitivanje bio potpuno besmislen, s obzirom na vreme koje bi bilo potrebno da se postavi verodostojna dijagnoza.

Nakon sprovedenog postupka, Zemaljski sud u Minhenu je presudio sledeće: 1) Arbitražni sporazum koji je zaključen između stranaka je ništav zbog nepostojanja alternative za stranke; 2) Ništavost arbitražnog sporazuma ne sprečava priznavanje arbitražne odluke; 3) Zahtev za naknadu imovinske i neimovinske štete ne postoji (nije osnovan) jer je zabrana takmičenja zbog dopinga bila opravdana; 4) Sud je vezan za činjenično stanje koje je utvrdio arbitražni sud i mora bez daljeg ispitivanja poći od toga da je izrečena zabrana bila pravovaljana. ${ }^{17}$

Zemaljski sud u Minhenu je stanovište o ništavosti arbitražnog sporazuma obrazložio time da Pechstein kada je potpisivala arbitražni sporazum nije imala mogućnost izbora da ne potpiše taj sporazum. Pechstein je profesionalna klizačica (brzo klizanje) nasuprot koje stoje savezi koji na nacionalnoj i međunarodnoj razini imaju monopolski položaj jer za brzo klizanje postoji samo jedan krovni nacionalni i jedan krovni međunarodni savez. Da bi Nemački klizački savez uopšte podržao

16 Interesantno je da je Pechstein nakon isteka suspenzije i nako što je nastavila da se takmiči sama sebe prijavila Međunarodnoj klizačkoj uniji, Nacionalnoj antidoping agenciji Nemačke i Svetskoj antidoping agenciji zbog dopinga, pošto je i dalje imala povećane vrednosti u krvi Retikulozytena. Međunarodna klizačka unija se o tome nije uopšte izjašnjavala, WADA se proglasila nenadležnom, a NADA je konstatovala da iz prijavljenih vrednosti Retikulozytena u krvi Pechstein ne proizilazi dokaz dopinga.

17 Urteil LG München, Az. 37 O 28331/12, 26. II. 2014., http://www.dis-arb.de/de/47/datenbanken/ rspr/lg-münchen-az-37-o-28331-12-datum-2014-02-26-id1585. 
i prijavio Pechstein za učešće na međunarodnim takmičenjima, ona je morala da sa savezom potpiše arbitražni sporazum. Takođe, bez potpisivanja arbitražnog sporazuma sa ISU-om, Pechstein bi bilo nemoguće da učestvuje na Svetskom prvenstvu u Hamaru. Učešće, pak, na takmičenjima koje organizuje Međunarodna klizačka unija, je za Pechstein, imajući u vidu monopolski položaj ovog saveza, jedina mogućnost da svoj poziv vrši na primeren način i da se takmiči sa drugim profesionalnim konkurentnima. Kako je Pechstein kroz učešće na takmičenjima pribavljala novac za svoje izdržavanje, uključujući i novac od sponzora, to za nju faktički nije postojala nikakva druga mogućnost nego da potpiše arbitražni sporazum. Imajući u vidu hijerarhijsku strukturu i monopolski položaj saveza u odnosu na sportiste, tužilja i tuženi savezi nisu ravnopravne stranke već između njih postoji "strukturalna nejednakost". Na osnovu izrazite nadmoćnosti saveza nad sportistima, savezi su bili u poziciji da faktički jednostrano odrede sadržinu arbitražnog sporazuma. Zbog ovoga može se smatrati da je postojalo odsustvo dobrovoljnosti pri potpisivanju arbitražnog sporazuma, zbog čega je on ništav. Okolnost da tužilac nije prigovarao ili osporavao nadležnost arbitražnog suda ne ukazuje sama po sebi da je postojala dobrovoljnost (slobodna volja) ugovornih strana. Prema shvatanju suda, odsustvo dobrovoljnosti ne mora se eksplicitno manifestovati, već može proisticati i iz datog prinudnog stanja.

Zemaljski sud $\mathrm{u}$ Minhenu je prethodno navedeno stanovište zasnovao, kada je $\mathrm{u}$ pitanju Nemački klizački savez kao tuženi, na par. 138. st. 1. nemačkog Građanskog zakonika, prema kome je neki pravni posao ništav ako je suprotan dobrim običajima, koji se, pak, sadržinski određuju prema pravnom poretku imanentnim pravnoetičkim vrednostima i principima ${ }^{18}$ i prema vladajućem socijalnom moralu. Zaključeni arbitražni sporazum je vodio ka neuobičajeno teškim posledicama po Pechstein jer joj je oduzeo pravo na pristup redovnim sudovima. Takvo dejstvo se ne može opravdati načelom privatne autonomije koje je sadržano u čl. 2. st. 1 . Osnovnog zakona Nemačke, pošto u situaciji kada postoji strukturna podređenost jedne strane drugoj, podređenoj strani se privatna autonomija (sloboda ugovaranja) može jemčiti samo putem ograničenja privatne autonomije za nadređenu stranu. Doduše, moguće je da se stranke putem arbitražnog sporazuma odreknu zaštite pred državnim sudovima i da spor povere na rešavanje određenom arbitražnom sudu, međutim jedno takvo odricanje je punovažno samo ako ima osnovu u punoj privatnoj autonomiji stranaka i ako je ostavljena mogućnost državi da kontroliše zloupotrebe privatne autonomije stranaka. Dobrovoljnost je osnovna pretpostavka za odricanje od mogućnosti obraćanja redovnim sudovima putem arbitražnog sporazuma. Pošto je u konkretnom slučaju savez pri potpisivanju arbitražnog sporazuma imao izrazitu nadmoćnost nad sportistom, to klauzula sadržana u arbitražnom sporazumu o odricanju sportiste od obraćanja redovnim sudovima ne može se smatrati aktom samoodređenja sportiste. Arbitražni sporazum sa sportistom koji se nalazi u podređenom položaju može biti punovažan samo ako sportista ima

18 Sud je tu posebno ukazao na principe sadržane u čl. 20. Osnovnog zakona (Ustava) Nemačke: princip pravne države (u koji spada i pravo na pristup sudu, kao jedno od elementarnih pretpostavki za funkcionisanje jedne demokratske pravne države) i princip socijalne države. 
punu i pravu mogućnost izbora da li će konkretne sporove rešavati redovni sudovi ili određeni arbitražni sud. Dobrovoljnost je osnovni uslov za jedan arbitražni sporazum i osnovna karakteristika arbitražnog reševanja sporova.

Prema stanovištu Zemaljskog suda u Minhenu, arbitražni sporazum između Pechstein i ISU-a je ništav na osnovu čl. 27. st. 2. švajcarskog Građanskog zakonika prema kome se niko ne može odreći svoje slobode niti se ograničiti u njenom korišćenju putem povrede prava ili morala. Zaštita prava putem državnih sudova predstavlja u švajcarskom pravu zaštićeno lično dobro, pa i arbitražni sporazum može predstavljati povredu čl. 27. st. 2. Građanskog zakonika. Zemaljski sud u Minhenu nije prihvatio prigovor ISU-a da je u švajcarskoj sudskoj praksi prihvaćena punovažnost arbitražnih sporazuma između sportista i sportskih saveza u kojima je isključena mogućnost obraćanja redovnim sudovima, bez obzira na strukturnu nadmoćnost saveza nad sportistom, pošto su takvi sporazumi u "pretpostavljenom interesu" sportista imajući u vidu brzo rešavanje sporova putem dovoljno nezavisnog, nepristrastnog i specijalizovanog arbitražnog suda, kakav je CAS. Po shvatanju Zemaljskog suda u Minhenu, takvo stanovište se ne može prihvatiti jer je suprotno garanciji sadržanoj u čl. 6. i 13. Evropske konvencije o ljudskim pravima, a nije u skladu ni sa praksom Evropskog suda za ljudska prava koji je zauzeo stanovište da arbitražni sporazum da bi bio punovažan mora biti dobrovoljan, dopušten i jednoznačan (slučaj Suda protiv Češke Republike, 28. X. 2010, 1643/06, Br. 48).

Zemaljski sud u Minhenu je posebno ukazao i da je Evropski sud za ljudska prava u svojim odlukama postavio i sadržinska merila za arbitražne postupke. Ukoliko arbitražni sporazum nije dobrovoljno zaključen, jer je bio unapred pripremljen na osnovu zakona ili od nekog trećeg lica, onda je takav arbitražni postupak moguć samo ako su obezbeđene garancije iz čl. 6. Evropske konvencije o ljudskim pravima, posebno zahtevana nezavisnost tela koje odlučuje. Kada su u pitanju arbitri CAS-a, te pretpostavke nisu obezbeđene. Arbitražne sudije se imenuju prema čl. R33 CAS Code sa zatvorene Liste, na čije sastavljanje sportisti nemaju skoro nikakv uticaj. Sportisti nemaju pravo predlaganja kandidata za Listu arbitara, već samo sportski savezi. Time je institucionalizovana nadmoćnost saveza, što je u suprotnosti za nezavisnošću arbitražnih sudija. Pod znakom pitanja je i pravo imenovanja predsednika arbitraže, odnosno arbitražnog veća od strane generalnog sekretara CAS-a, u netransparentnom postupku iz čl. R40.2 i čl. 54. st. 3. CAS Code. Konačno, nije u skladu sa nezavisnošću arbitraže i obaveza arbitra, odnosno arbitražnog veća da podnese nacrt odluke na uvid generalnom sekretaru CAS-a. Ovi prigovori nezavisnosti CAS-a, odnosno arbitara od strana u sportu mogli bi se "tolerisati" u situaciji kada ih stranke doborovoljno prihvataju, ali oni nisu u skladu sa čl. 6. Evropske konvencije o ljudskim pravima u situaciji kada je arbitražni sporazum pravno ili faktički nametnut.

Bez obzira na prethodno iznete nedostatke arbitražnog sporazuma i nedostatke u pogledu nezavisnosti arbitraže (CAS), Zemaljski sud u Minhenu je našao da je arbitražna odluka CAS-a punovažna i konačna i obavezujuća za nemački sud. Kako je reč o stranoj arbitražnoj odluci, njeno priznavanje i izvršenje se sprovodi 
na osnovu par. 1061. stav 1. nemačkog Zivilprecessordnung i odredaba Njujorške konvencije. U konkretnom slučaju postoje sve formalne pretpostavke za priznavanje sporne arbitražne odluke, a ne postoje razlozi navedeni u čl. V, st. 1. i 2. Njujorške konvencije za odbijanje priznanja. Stav suda da je arbitražni sporazum nepunovažan zbog odsustva dobrovoljnosti stranaka nije prepreka za priznavanje arbitražne odluke CAS-a jer tužilja (Pechstein) nije tokom arbitražnog postupka prigovarala punovažnosti arbitražnog sporazuma. Ona je u arbitražnom postupku bila zastupana od advokata i mada je znala da nije dobrovoljno potpisala arbitražni sporazum, sama je podnela žalbu CAS-u i potpisala pravila postupka pred ovim arbitražnim sudom. Stranka koja ne prigovori, odnosno ne istakne u arbitražnom postupku nedostatke arbitražnog sporazuma, prekludirana je u pravo da to kasnije ističe. Prekluzivno dejstvo nije eksplicitno navedeno u Njujorškoj konvenciji, ali ono proističe iz zabrane protivurečnog ponašanja, koja je imanentna Njujorškoj konvenciji. ${ }^{19}$

Protivi navedene presude Zemaljskog suda u Minhenu Pechstein je podnela žalbu Višem zemaljskom sudu u Minhenu i to samo u delu presude koja se odnosila na ISU. Viši zemaljski sud je žalbu delimično prihvatio tako što je preinačio presudu Zemaljskog suda u Minhenu u delu u kome je odbijen zahtev tužilje za naknadu štete. I Viši zemaljski sud nije prihvatio zahtev tužioca da se utvrdi da je zabrana nastupa na takmičenjima zbog dopinga nedopuštena. ${ }^{20}$ To, međutim, ne znači da sud prihvata punovažnost odluke CAS-a. Prema stanovištu suda, arbitražna odluka CAS-a je neobavezujuća za sud u odnosu na pitanje osnovanosti zahteva za naknadu štete, jer nisu ispunjeni uslovi za priznanje strane arbitražne odluke u skladu sa Njujorškom konvencijom. Priznavanje odluke CAS-a bilo bi u suprotnosti sa nemačkim javnim poretkom (ordre public). Povreda javnog poretka postoji uvek kada je dejstvo određene odluke očigledno nespojivo sa suštinskim načelima nemačkog prava, i ona u tom smislu povređuje elementarne osnove pravnog poretka. $\mathrm{U}$ te elemente javnog poretka spada prema Njujorškoj konvenciji i kartelno pravo. ISU-u je sa stanovišta kartelnog prava zabranjeno da zahteva od sportiste arbitražni sporazum o nadležnosti CAS-a, uz isključenje obraćanja redovnim sudovima, jer su ti zahtevi zloupotreba monopolskog položaja na tržištu. ${ }^{21}$

Presuda Višeg zemaljskog suda u Minhenu je suštinski zasnovana na osnovnom stavu suda da ISU podleže kartelnom pravu jer je na relevantnom tržištu organizovanja svetskih prvenstava u brzom klizanju monopolista, odnosno preduzetnik koji ima dominantan položaj na tržištu, u smislu par. 19. Zakona o zabrani ograničenja konkurencije (Gesetz gegen Wettbewerbsbeschränkungen GWB). Privredna delatnost je svaka ona koja se sastoji u tome da je dobra ili usluge

19 Više o značaju presude Zemaljskog suda u Minhenu videti, Lukas Handschin - Tony M. Schuetz, Bemerkungen zum Fall „Pechstein“, Sport und Recht, 5/2014, str. 179-181.

20 Prema stanovištu suda, tužba za utvrđenje može da se odnosi samo na utvrđenje postojanja ili nepostojanja nekog pravnog odnosa, u šta mogu spadati i prava i obaveze iz određenog odnosa, ali ne i na utvrđenje elemenata pravnih odnosa, činjenica, punovažnosti izjave volje ili protivpravnosti određenog ponašanja (to je i stanovište nemačkog Vrhovnog saveznog suda).

${ }^{21}$ Videti, OLG München· Teil-Urteil vom 15. Januar 2015 · Az. U 1110/14 Kart, http://openjur. de/u/756385.html. 
nude na određenom tržištu. Ukoliko je taj uslov ispunjen, okolnost da je delatnost povezana sa sportom nije prepreka za primenu propisa o zabrani ograničenja konkurencije. Sportska udruženja i savezi se moraju posmatrati kao preduzetnici kada obavljaju delatnost na tržištu sportskih priredbi putem nuđenja odgovarajućih usluga. U konkretnom slučaju se radilo o tržištu vezanom za sprovođenje svetskih prvenstava u brzom klizanju. S obzirom na hijerarhijsku strukturu i princip jedan savez u klizanju, Svetska klizačka unija je jedini nudilac usluga u svojoj grani sporta koji nema konkurenciju, pa je samim tim monopolista. Preduzetnicima koji, pak, imaju dominantan položaj na tržištu je na osnovu par. 19. GWB zabranjeno da stvaraju uslove poslovanja koji odstupaju od onih koji se očekuju sa velikom verovatnoćom kod postojanja delotvorne konkurencije. Pojam uslova poslovanja se veoma široko tumači i obuhvata sve što se može uobličiti putem ugovornih odredbi, tako da i sporazum o nadležnosti arbitražnog suda uz isključenje nadležnosti državnih sudova tu spada. Poštujući ovu zabranu, ISU nije smela da zahteva od Pechstein zaključenje arbitražnog sporazuma od 2. januara 2009. godine.

Viši zemaljski sud nije, međutim, prihvatio stanovište Zemaljskog suda u Minhenu o ništavosti arbitražnog sporazuma zbog postojanja nadmoćnosti saveza nad sportistom i nedostatka dobrovoljnosti na strani sportiste. Prema stanovištu Višeg zemaljskog suda, zahtevanje od strane organizatora međunarodnih sportskih takmičenja da sportisti učesnici potpišu arbitražni sporazum nije samo po sebi zloupotreba tržišne moći niti prinuda koja isključuje slobodnu volju onih koji bi da učestvuju na takmičenju. Šta više, za takve zahteve postoje značajni opravdani razlozi. Posebno jer se na taj način putem jedinstvene nadležnosti i uređenja postupka može sprečiti da se u istovetnim slučajevima donose različite odluke od strane nacionalnih sudova, što sve služi garanciji obezbeđenja jednakih šansi za sve sportiste koji učestvuju na takmičenju. Član 6. st. 1. Evropske konvencije o ljudskim pravima načelno sprečava primenu na konkretni slučaj arbitražnog sporazuma sa kojim jedna strana u sporu nije saglasna. Ali kada određeni arbitražni sporazum postoji, sama okolnost da je sporazum bio ekonomski nužan da bi neko mogao da vrši određenu poslovnu delatnost, ne vodi do povrede garancije iz člana 6. st. 1 . Evropske konvencije o ljudskim pravima.

Međutim, Viši zemaljski sud u Minhenu je našao da je ISU zloupotrebila tržišnu moć time što je zahtevala arbitražni sporazum u korist CAS-a. Razlog je jednostavan. CAS ne nudi garanciju strukturno neutralnog arbitražnog suda zbog načina imenovanja arbitara. U procesu imenovanja arbitara CAS-a, savezi imaju ogromnu nadmoć nad sportistima u pogledu uticaja na izbor lica koji će doći u obzir kao arbitri. Prema CAS Code, stranke mogu u konkretnom sporu isključivo izabrati arbitre sa Liste arbitara koju sastavlja ICAS (International Council of Arbitration for Sport), telo koje upravlja CAS-om. Ovo telo se, pak, sastoji od 20 članova od kojih: četiri koje imenuju međunarodni savezi, četiri koje imenuju nacionalni olimpijski komiteti i četiri koje imenuje Međunarodni olimpijski komitet. Ovih 12 članova ICAS-a imenuju dodatna četiri člana koji će čuvati interese sportista, a onda 16 imenovanih članova imenuju još četiri člana koji su nezavisni od organizacija koje imenuju druge članove. Pri imenovanju ovih dodatnih 8 članova ICAS-a ne postoji 
posebna odgovarajuća procedura za ta imenovanja pa su, po pravilu, i ti članovi povezani sa sportskim savezima jer samo od članova ICAS-a koji ih biraju zavisi procena ispunjenosti kriterijuma za izbor. Inače, sve odluke ICAS donosi prostom većinom. Prilikom izbora arbitara za CAS, ICAS treba da uzima, načelno, u obzir sledeću raspodelu: 1/5 arbitara treba da bude iz kruga lica koje je predložio MOK; 1/5 arbitara treba da bude iz kruga lica koje su predložili međunarodni sportski savezi; 1/5 arbitara treba da bude iz kruga lica koje su predložili nacionalni olimpijski komiteti; $1 / 5$ arbitara treba da bude izabrana s obzirom na očuvanje interesa sportista i 1/5 arbitara treba da bude izabrana iz kruga lica koja su nezavisna od organizacija koje su predložile druge arbitre. Ovakav način izbora arbitara dovodi ozbiljno u pitanje neutralnost CAS-a i stvara rizik da su lica koja su stavljena na Listu arbitara većinski ili u potpunosti blisko povezani sa savezima. Time je doveden u pitanje i lični integritet imenovanih arbitara pošto postoji ozbiljan rizik da im budu "bliža" stanovišta saveza nego sportista. Ovakva nadmoćnost saveza nije otklonjena ni time što Lista arbitara ima najmanje 150 članova, pošto rizik za povezanost sa savezima postoji kod svakog pojedinog arbitra. Strukturalna nejednakost u korist saveza ogleda se i u tome da u žalbenom postupku pred CAS-om predsednik arbitražnog veća koje odlučuje u konkretnom slučaju određuje predsednik Žalbenog odeljenja CAS-a, ako se strane u sporu o tome ne dogovore. Predsednika Žalbenog odeljenja, pak, imenuje ICAS, u kome su većina predstavnici saveza. U sporovima između saveza i sportista koji se vode pred CAS-om ne postoji sinhronizacija njihovih interesa, već su oni suprotstavljeni, tako da se opravdanje za nadmoćnost saveza ne može naći u zajedničkim interesima saveza i sportista, pa čak ni u tome da su funkcioneri saveza veoma često bivši sportisti.

Viši zemaljski sud u Minhenu nije našao ni da učešće tužioca u arbitražnom postupku pred CAS-om predstavlja protivurečno ponašanje koje bi isključilo mogućnost obraćanja redovnom sudu. Prema svom tekstu, arbitražni sporazum je pokrio veliki broj mogućih sporova. Međutim, to što je tužilac pokrenuo spor pred CAS-om u pogledu izrečene zabrane nastupa na takmičenjima usled dopinga, ne protivureči tome da ima pravo da podnese zahtev redovnom za naknadu štete zbog nametanja (sprovođenja) zabrane takmičenja. Čak i kada se uzme da podnošenje žalbe CAS-u predstavlja priznanje nadležnosti CAS-a da proveri izrečene zabrane, time se priznanje ne proširuje i na sve druge moguće sporove između stranaka. ${ }^{22}$

Protiv presude Višeg zemaljskog suda u Minhenu podneta je revizija Vrhovnom saveznom sudu Nemačke. U sportskim, ali i pravničkim krugovima se sa nestrpljenjem ali i zebnjom očekivala presuda Vrhovnog saveznog suda. Ona je konačno doneta 7. juna 2016. godine ${ }^{23}$ i u njoj je preinačena presuda Višeg zemaljskog suda u Minhenu i odbijen tužbeni zahtev Pechstein u potpunosti,

22 O ovoj presudi više videti, Fabio Adinolfi - Tillmann Ruebben, "Der Fall Pechstein ind die Zukunft der Sportgerichtsbarkeit - Entscheidungsanmerkung”, Zeitschrift fue das Juristische Studium, 3/2016, str. 382-385.

23 Bundesgerichtshof - BGH, KZR 6/15, 7. juni 2016, http://lexetius.com/2016,1518. 
odnosno tužba je proglašena nedopuštenom jer protiv nje stoji prigovor postojanja arbitražnog sporazuma. ${ }^{24}$ Prema stanovištu Vrhovnog saveznog suda Nemačke:

1) CAS je „pravi“ arbitražni sud u smislu par. 1025. st. 2. i par. 1032. st. 1. Zivilprocessordnung, a ne samo organ saveza ili neko drugo telo za rešavanje sporova. ${ }^{25}$ Sudska delatnost $\mathrm{u}$ nemačkom pravnom poretku pretpostavlja poštovanje zahteva „distance“ i „,neutralnosti“. Ti zahtevi važe bez izuzetka i kada su u pitanju arbitražni sudovi. Shodno tome, „pravi“ arbitražni sud, putem koga se može punovažno isključiti obraćanje redovnim sudovima, postoji samo tada kada odluka arbitražnog suda predstavlja odluku nezavisne i neutralne instance. CAS predstavlja takvu nezavisnu i neutralnu instancu. On nije sastavni deo nekog određenog saveza ili udruženja, već je kao institucija nezavistan od vodećih sportskih saveza i olimpijskih komiteta, tako da je u stanju da osigura jedinstvenu sudsku praksu za sve saveze.

2) Međunarodni sportski savez koji je organizovan po principu „jednog mesta“ (samo jedan savez na vrhu u jednom sportu) ima dominantan položaj na tržištu u pogledu dopuštanja sportistima da učestvuju na sportskim takmičenjima koje on organizuje.

3) Ne predstavlja zloupotrebu tržišne moći od strane sportskog saveza kada on uslovljava učešće sportista na sportskom takmičenju potpisivanjem arbitražnog sporazuma, u kome je shodno Antidoping pravilima predviđena nadležnost CAS-a kao arbitražnog suda. Pravila postupka pred CAS-om sadrže dovoljne garancije za očuvanje prava sportista i arbitražna odluka CAS-a podleže kontroli švajcarskog Saveznog suda.

4) CAS pravila arbitražnog postupka nisu manljiva usled nedovoljne garancije za očuvanja prava sportista koja bi proisticala iz toga da stranke u postupku biraju arbitre sa zatvorene Liste koja se sastavlja od tela koje u svom sastavu ima većinu predstavnika MOK-a, nacionalnih olimpijskih komiteta i međunarodnih sportskih saveza. Način obrazovanja Liste arbitara dovodi u pitanje potrebnu nezavisnost „pravog" arbitražnog suda samo onda kada se njim institucionalizuje nadmoćnost jedne strane ili kada je telo koje ima odlučujući uticaj na ustanovljenje liste arbitara „bliže“ interesima jedne strane nego druge. Lista arbitara CAS-a ne manifestuje bilo kakvo institucionalizovanje nadmoćnosti određenog, u konkretnom arbitražnom sporu učestvujućeg sportskog saveza, u smislu da on ima direktan uticaj na sastav Liste.

24 Značajno je istaći i da je Vrhovni savezni sud odbio u potpunosti zahtev ISU-a da se ukine presuda Zemaljskog suda u Minhenu od 26. februara 2014. godine u delu u kome je postala pravnosnažna, jer nemački klizački svez nije učestvovao ni u žalbenom ni u revizionom postupku.

25 Videti, Viktoriya Pashorina Nichols, Is the Court of arbitration for sport really arbitration?, Laws 521: International arbitration \& Dispute settlement, University of Wellington, 2015., http://researcharchive. vuw.ac.nz/xmlui/bitstream/handle/10063/5007/paper.pdf?sequence=1 . 
Međunarodna klizačka unija ima, kao i bilo koji drugi pojedinačni međunarodni savez, samo „,izvesni“ uticaj na sastavljanje liste arbitara, kroz pravo predlaganja $1 / 5$ arbitara, ali taj uticaj nije takvog stepena da se može smatrati „odlučujućim“ uticajem na sastavljanje Liste arbitara CAS-a. Osim toga, nadmoćnost u konkretnom sporu određenog sportskog saveza prema sportisti u pogledu procedure imenovanja arbitara može predstavljati povredu nezavisnosti i neutralnosti arbitražnog suda samo onda kada savezi sportisti stoje jedan nasuprot drugog sa suprotstavljenim interesima (takav je, na primer, odnos između poslodavca i radnika). Konačno, CAS-Code obezbeđuje dovoljnu individualnu nezavisnost $i$ neutralnost arbitra u konkretnom sporu. Arbitar nakon imenovanja mora potpisati izjavu da će svoju funkciju obavljati objektivno i nezavisno, on ne može $u$ isto vreme biti i član ICAS-a, i mora objaviti svaku okolnost koja bi mogla ugroziti njegovu nezavisnost prema strankama u sporu. Nasuprot tome, stranka koja sumnja u nezavisnost određenog arbitra može odbiti njegovo imenovanje zbog pristrasnosti. Okolnost da generalni sekretar CAS-a ima pravo prethodnog uvida u nacrt arbitražne odluke i mogućnost da stavi određene primedbe ne dovodi u pitanje nezavisnost arbitraže već je u funkciji ujednačavanja sudske (arbitražne) prakse.

5) Nezavisnost CAS-a nije dovedena u pitanja usled načina izbora arbitara, posebno zbog toga što sportski savezi i sportisti, kada je u pitanju borba protiv dopinga, načelno nemaju suprotstavljene interese i pozicije. Kada je reč o obezbeđenju sporta bez dopinga, i savezi i sportisti imaju pretežno istovetne interese. I sportski savezi i sportisti imaju zajednički interes da se pretpostavljeni prekršaji antidoping pravila na međunarodnom nivou ispituju i sankcionišu prema jedinstvenim merilima i na isti način, nezavisno od toga iz koje zemlje dolaze sportisti. Takav pristup i univerzalno priznavanje donetih odluka može da obezbedi samo nezavisni i fer arbitražni sud, kakav je CAS.

6) Pod takvim okolnostima, zaključeni arbitražni sporazum nije nepunovažan niti sa stanovišta zaštite prava na pristup sudu iz čl. 2. st. 1. Osnovnog zakona i prava na slobodno obavljanje profesije iz čl. 12. st. 1. Osnovnog zakona, niti sa stanovišta prava na pošteno suđenje iz čl. 6. st. 1. Evropske konvencije o ljudskim pravima. Zaključeni arbitražni sporazum je u okvirima autonomije sporta. Arbitražni sporazum stranaka od 9. januara 2009. godine obuhvatao je sve zahteve, uključujući i zahteve za naknadu štete, koje bi sportista koji učestvuje na takmičenju imao prema ISU-u. Kako je arbitražni sporazum prema merilima iz par 19. Zakona o zabrani ograničenja konkurencije (GWB) i sa stanovišta par. 138. Građanskog zakonika (BGB) punovažan, to je tužba Pechstein za naknadu štete nedopuštena. 


\section{ZAKLJUČNO RAZMATRANJE}

Presuda Saveznog vrhovnog suda Nemačke je izazvala ogromno interesovanje u stručnim krugovima još pre svog donošenja, a čekana je sa velikom zebnjom od strane CAS-a, Međunarodnog olimpijskog komiteta i međunarodnih sportskih saveza. Čak su i pojedini nemački političari tokom trajanja postupka izražavali zabrinutost za položaj nemačkog sporta u međunarodnim okvirima ukoliko Vrhovni savezni sud potvrdi nižestepene presude.

Pechstein je presudu nemačkog Vrhovnog saveznog suda prokomentarisala rečima: „Svaki izbeglica koji dođe u Nemačku i registruje se ima mogućnost pravne zaštite, ali ne i mi sportisti." Slučaj Pechstein nije, međutim, odlukom Vrhovnog saveznog suda Nemačke i definitivno okončan pošto je nezadovoljna i odlukom ogorčena sportistkinja najavila obraćanje Ustavnom sudu Nemačke i Evropskom sudu za ljudska prava.

Presuda Vrhovnog saveznog suda Nemačke je u krugovima bliskim CAS-u i međunarodnim sportskim savezima naišla na široko odobravanje, ali su zato u nemačkim medijima i pravnoj literaturi prisutne kako pohvale tako i brojni prigovori. Tako se, na primer, ukazuje: da se sud nije na generalan način izjasnio o punovažnosti arbitražnih sporazuma o nadležnosti CAS-a koji su sadržani u statutima i prijavama za takmičenje međunarodnih sportskih saveza već samo u kontekstu borbe protiv dopinga u sportu; da je sud, sakrivajući se iza autonomije sporta, propustio priliku da se stavi pod kontrolu (između ostalog i obraćanjem Evropskom sudu pravde) profesionalnom sportu imanentna netransparentnost i odsustvo unutrašnje demokratije koji vode korupciji (FIFA skandal) i zataškavanju dopinga (IAAF); sud je svojom presudom pokrio strukturne mane postojećih sportskih arbitraža, posebno u pogledu jednakog očuvanja interesa sportista i saveza; sud je presudio na osnovu pogrešnog činjeničnog stanja jer je prevideo da predsednik Žalbenog odeljenja CAS-a imenuje predsednika arbitražnog veća uvek a ne samo ako se od stranaka imenovani arbitri o tome ne saglase; potvrđena je odluka CAS-a koja je očigledno neobrazložena; sud se očigledno opredelio za konzervatizam i konformizam; stav suda da je Pechstein dobrovoljno prihvatila arbitražni sporazum, iako da ga nije potpisala, ne bi mogla da učestvuje na takmičenju, je izvan svake realnosti pošto je CAS arbitraža uvek prinudna arbitraža, itd.

Bez obzira na to kako će se konačno okončati slučaj Pechstein, može se konstatovati da je ovaj slučaj otvorio pitanje demokratizacije rada CAS-a, posebno u pogledu izbora arbitara i uvažavanja interesa svih učesnika u sistemu sporta, koje se neće zatvoriti nakon presude Vrhovnog suda Nemačke. Uspostavljanje balansa između potreba za osiguranje autonomije sporta i potrebe da se učesnicima obezbedi delotvorna i pravična zaštita osnovnih ljudskih i ekonomskih prava predstavljaće i u budućem vremenu izazov kako za pravnike tako i za sportske saveze, sportiste, trenere, CAS i druge aktere na sportskoj sceni. Treba sigurno da zabrine rastuće nepoverenje među sportistima u pogledu postojećeg sistema obezbeđenja „pravde u sportu“", i presude nemačkih sudova neće okončati rasprave o adekvatnom 
arbitražnom sistemu za sportiste. ${ }^{26}$ Nedavno objavljena studija profesora Johna Ruggie sa Harvarda o upravljanju i ljudskim pravima u okvirima FIFE ${ }^{27}$ jedan je od radova koji ukazuju na važnost pronalaženja opšteprihvaćenog sistema arbitražnog rešavanja sporova u sportu. Jedno je, ipak, sigurno, pravna razmatranja arbitražnog sistema u sportu, koja su izneta tokom vođenja sporova pred nemačkim sudovima, imaju i imaće veliki uticaj na uobličavanje kako međunarodnih tako i nacionalnih stalnih sportskih arbitraža. Da bi neka institucionalna sportska arbitraža mogla da se prizna za „pravu“ arbitražu, ona mora kako ukupnom organizacijom tako i proceduralnim pravilima da osigura svoju nezavisnost i nepristrastnost od potencijalnih strana u sporu i da svojim ukupnim delovanjem uveri sve učesnike $u$ sistemu sporta da će kada odu na arbitražu „,dobiti pravdu“ i da će njihova ljudska i druga prava biti adekvatno i efektivno zaštićena.

\section{THE PECHSTEIN CASE - VALIDITY OF THE LAUSANNE- BASED COURT OF ARBITRATION FOR SPORT DECISIONS AND THEIR RECOGNITION IN FRONT OF NATIONAL COURTS}

Comparative law solutions encourage resolving disputes in the area of sport through arbitration, and instigation of court proceedings is forbidden by the rules of many national sport associations under the sanction of barring the athlete from international competing. The most important and most popular arbitration court for resolving the international disputes in the area of sport is the Court of Arbitration for Sport - CAS based in Lausanne (Switzerland). Jurisdiction will be given to the CAS if it is competent for arbitration and if there is valid arbitration agreement. Furthermore, same procedural demands apply to the CAS decisions as for the ruling of national courts: judicial independence, the right of the party to a hearing, the right to a fair trial, forbidding ex post facto laws and sanctions, principle ne bis in idem, principle of proportionality of punishment, principle of a judge impartiality, principle of reasoning behind the decision made in writing. In his paper, the author considers the issue of validity and enforceability of the decisions made by the CAS, and possibility of their denial in front of national courts according to headquarters of the CAS, as well as national courts of the parties to a dispute (in the proceedings of enforcement of the CAS decisions or regardless of that). This issue is particularly considered in the light of so-called Pechsteins case (complaint of Claudia Pechstein against the International Skating Union requesting compensation for receiving two-year ban from competition because of doping results) which was resolved by the ruling of the German Federal Court (Bundesgerichtshof) from 07 $7^{\text {th }}$ June, 2016, and where it was dealt exactly with validity of the arbitration agreement on the CAS jurisdiction and recognition of the CAS ruling as a foreign arbitration decision by the German national courts.

Key words: sports, arbitration, Pechstein, doping, arbitration decisions, the CAS, arbitration agreement, impartiality of arbitrators.

26 Videti, Andy Brown, Analyisis: Pechsteing to appeal after German court throws out her case, www.sportsintegrityinitiative.com/analysis-pechstein-to-appeal-after-german-court-throws-out-her-case/

27 John G. Ruggie, FIFA \& Human Right, Harvard Kennedy School, 2016., http://www. sportsintegrityinitiative.com/wp-content/uploads/2016/04/Ruggie_FIFA_report_April2016.pdf. 